\title{
HEAT PUMP INSTALLATION AND GREENHOUSE EFFECT
}

\begin{abstract}
Proposal of heat pump installations for small cubic buildings have been presented. Main goal of heat pump is produce energy necessary for heating, ventilation and hot water. Influence of heat pump installation on greenhouse gases emission to the atmosphere during its properly operation has been discussed. Obtained value of greenhouse gases emission were recalculated to equivalent $\mathrm{CO}_{2}$ emission and compared to analogical emission from the same building without heat pump installation.
\end{abstract}

Keywords: heat pump, $\mathrm{CO}_{2}$ emission, global warming

\section{Introduction}

A lot of attention in modern world is turned on comfort, in particular meaning of it, especially on human feeling of physical comfort. It is directly connected with energy consumption necessary to keep the optimal comfort conditions in habitable buildings. There is simple correlation between comfort conditions maintain on precision level by user of installation and order of energy needed to system operation: if higher comfort level than more energy is necessary to preserve it. But there is the other side of our personal comfort feeling. Increasing energy consumption involve using more and more natural source of fuels as coal, gas, oil etc. The natural energy sources are shrinking fast and that is way the rational energy administration is so important. Combustion of natural fuels is the most common method to produce energy to heating, ventilation and hot water. As a by-product of heat production from natural sources power station generate the gases which are emitted to earth atmosphere. Most of gases emitted to ambient air are affected to environmental and are cause global warming. Therefore, technology using renewable energy from such sources as ground, ground water and sun become necessary. Application of new technology using energy from renewable sources allows to decrease unhealthy gases emission to atmosphere, in particularly $\mathrm{CO}_{2}$ as a main factor responsibly to successive increasing of global temperature on earth. This occurrence is common known as greenhouse effect. The analysis of installation using renewable energy source and its 
influence to total reduction of greenhouse gases to natural environmental was presented in this article.

\section{Heat pump operation principles}

In habitable buildings the heat pump as installation to heat production from renewable sources are installed. Heat pump makes real transformation of heat energy from low temperature source to state suitable for user by increasing it energy potential to higher temperature level (Fig. 1).

Essential element of heat pump is compressor, which consume electrical energy. This energy is delivering from power station what leads to greenhouse gases emission to environmental. Saying of greenhouse effect, on means the $\mathrm{CO}_{2}$ because it is responsible for global warming the most among other gases emitted from power station. Greenhouse gases are released to atmosphere and are accumulated in upper level makes effect compared to gashouse.

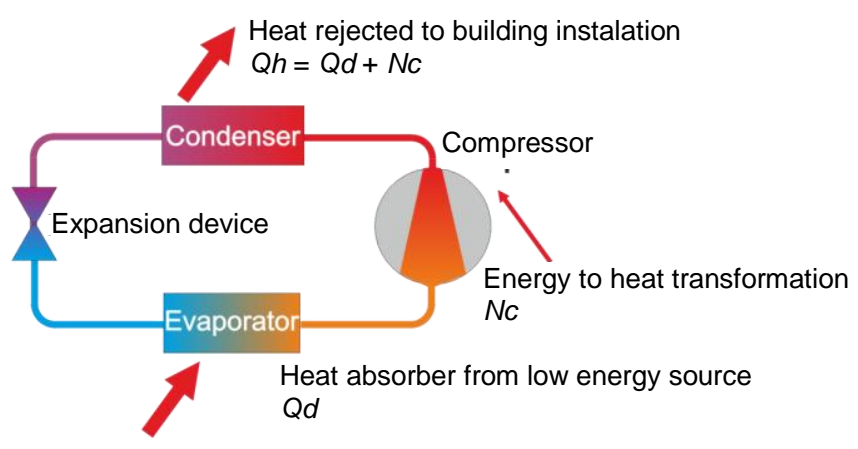

Fig. 1. Principle operation of compressor heat pump

Solar radiation is able to get through this boundary consist with accumulated gases by the cost of its energy decreasing. In other way, sun radiation wanted go out of earth atmosphere is impossible. Radiation is dissipated on surface of ground what due to energy dissipation to such small level that is impossible to get through the greenhouse gases in stratosphere. Than, sun radiation is reflected and go back to ground surface. This effect creates very unfavorable changes related to increasing of global temperature. To neutralize global warming the many different activities are done. All of it assume decreasing of greenhouse emission as dioxide carbon and other f-gases, for example refrigerants containing in its atom of fluor - F (as f-gas from HFC, HCFC, FC group etc.). There is a high possibility that one of $\mathrm{f}$-gases is using as operational thermodynamic fluid. It means, the heat pump itself is the source of greenhouse emitter. Factor, which allows to compare influence of selected refrigerant on global warming is 
GWP (Global Warming Potential). GWP describe influence of selected gases on greenhouse effect creation during 100 years time period compared to identical effect generated by $\mathrm{CO}_{2}$. For $\mathrm{CO}_{2}$ value of GWP is set to 1.0. The most common refrigerants and their GWP presented in Table 1 were include to analysis [1].

Table 1. Selected refrigerants to heat pump and GWP, based on [1]]

\begin{tabular}{|c|c|c|c|c|c|c|c|c|}
\hline Refrigerant & R600a & R134a & R143a & R404A & R407C & R410A & R507A & R744 \\
\hline GWP & 20 & 1300 & 4300 & 3800 & 1700 & 2000 & 3900 & 1,0 \\
\hline
\end{tabular}

Estimation of greenhouse gases emission (in manner of $\mathrm{CO}_{2}$ emission) from installation system contain heat pump and power station producing electricity needed to building installation operation and compare that result to analogical habitable building with typical condensation furnace is the main goal of this investigation research.

On level of greenhouse gases emission affect not only value of GWP but also mass of refrigerant stored in installation, recovery factor and leakage level. To obtain total effect of greenhouse gases emission, recalculated to equivalent $\mathrm{CO}_{2}$ emission from heat pump the TEWI (Total Equivalent Worming Impact) factor is more suitable [2]. TEWI allows to obtain total $\mathrm{CO}_{2}$ emission from installation of heat pump to atmosphere and as well as emission necessary to produce electricity to compressor operation. It means that the heating system with heat pump emit greenhouse gases from heat pump itself and also gases are emitted from power station to assure energy needed to compressor.

\section{Analysis of ground heat pump greenhouse gases emission}

To analysis the installation system with ground heat pump was selected. The heat pump serve all heating systems in detached house of $130 \mathrm{~m}^{2}$ usable surface. Building is habitable by 4 people. Heat pump supply heat energy to such systems as central heating, mechanical ventilation with cooling in summer time period and hot water preparation in winter. In summer hot water is prepared by solar collectors installation. Assumed, that mechanical ventilation is working 8 hour per day average in year. The air volume to ventilation in winter and in summer to cooling was set to $350 \mathrm{~m}^{3} / \mathrm{h}$. Heat pump for central heating, hot water and ventilation is working in monovalet system without any additional energy source. There is floor heating in building. The schema of that installation is presented in Fig. 2. 


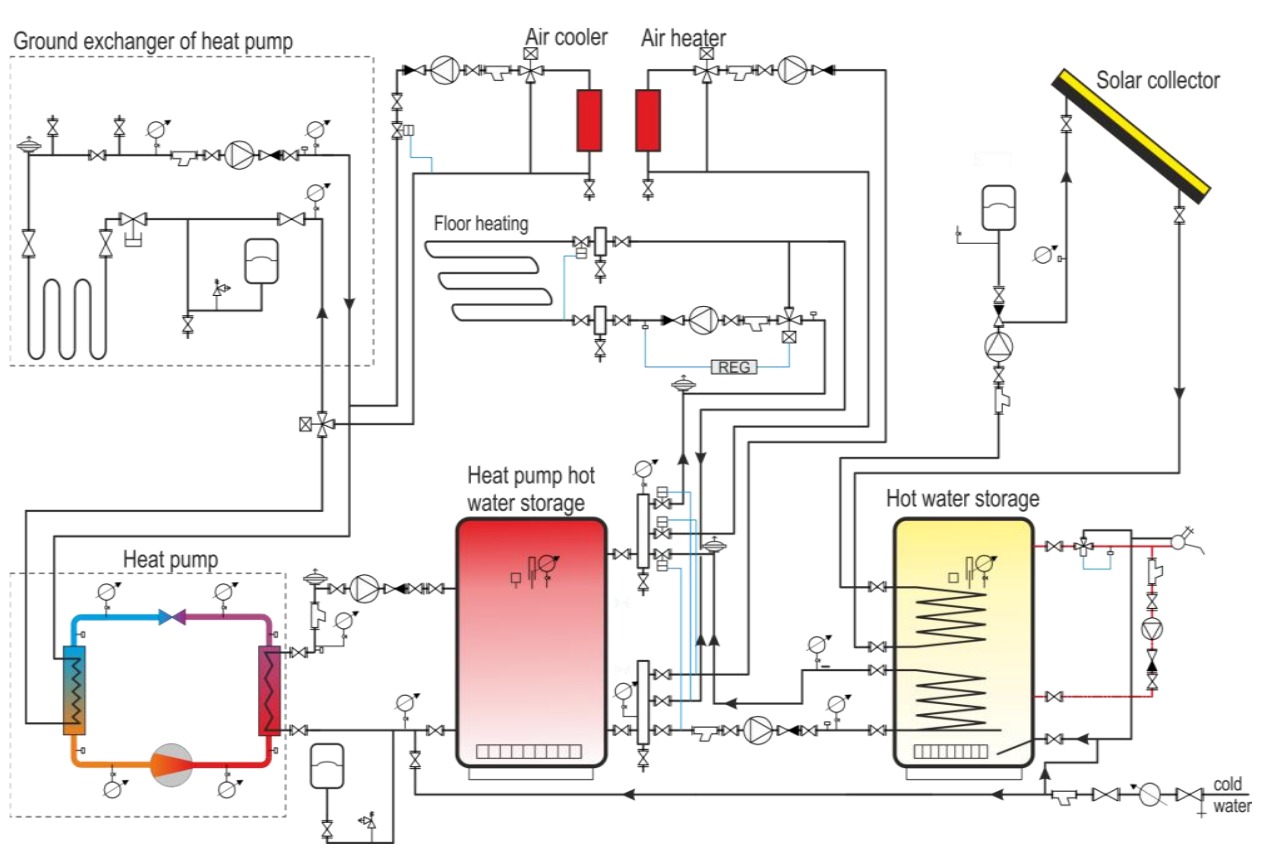

Fig. 2. Schema of analyzed installation with ground heat pump

In summer heat pump makes cool needed to air cooler and in the same time the heat pump hot water storage is charging. That behavior of installation leads to minimum solar collector operating cost and dimension of solar collector. Mechanical ventilation operate with heat recuperator of $50 \%$ annual efficiency. Also, the heat pump in summer period is available to work in passive mode. In selected range of time period in summer at ambient temperature not so high is possible to operate without compressor only circulating pump at air cooler can operate and pumping cooling agent (35\% polypropylene glycol and pure water mixture - trade name: ergolid - eko) from cool ground (approximately $12^{\circ} \mathrm{C}$ temperature at low source heat pump collector level) to air cooler in air - conditioning central unit. Such pre-cooled mixture is able to cool ventilation air to suitable comfort temperature. This installation solution allows to save a lot of energy, many and decreasing $\mathrm{CO}_{2}$ emission as well.

Due to possibility of comparison of $\mathrm{CO}_{2}$ emission from such installation the base version of installation was defined. Base version installation assumes the same building construction, energy demand and the same installation: floor heating, mechanical ventilation, hot water prepared from solar collector in summer. Different is only energy source. In this case natural gas is burned in condensation two - functional furnace producing heat for space heating and to air heater in ventilation box and as well as hot water preparation (second function of furnace). Energy to system operation is derived from two sources: electricity to 
drive of installation equipment from power station and gas. In first case, installation with heat pump all energy demand come from electricity (power station only). There is no any directly gas emission from any installation in building except leakage in heat pump and during servicing.

For that two variants of installation the annual energy consumption was obtain, separately for electricity and gas demand. The all calculation was made according to regulation of infrastructure ministry concern methodology of building energy certification [3]. Selected results from energy certificate for both, heat pump and traditional energy source installation are presented in Fig. 3.

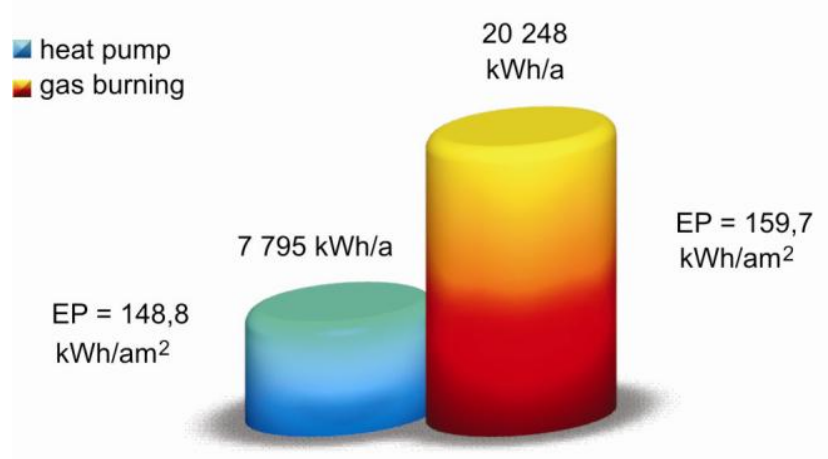

Fig. 3. Annual building energy demand and EP factor from energy certificate

According to Fig. 1 less energy demand to all heating and cooling installation and preparation of hot water has ground heat pump. The results of analysis show about $62 \%$ decreasing of energy consumption in case of heat pump systems mounted in building compared to traditional solution of space heating systems. The most important part of energy demand, and amount of $\mathrm{CO}_{2}$ emission to atmosphere, belong to space heating and mechanical ventilation (Table 2), it is 76 up to $83 \%$ of all energy consumption (less value for heat pump system).

Our comfort feeling, it means psychical and economical, depends on annual cost of system operation as well. Less operation cost gives user sense of financial independencies. Its important but often skipped part in analysis. The values of building energy demand are not as well known as necessary payment for keeping comfort physical and economical for being owner of installation which allows to prevent from dramatic depletion of natural non renewable energy sources. It does matter to be aware of ecological aspect of technology application in buildings cause this aspect of life affects on every people, whatever are aware of it or not. 
Table 2. Detailed energy demand analyzed variants of installation

\begin{tabular}{|c|c|c|c|c|}
\hline & \multicolumn{3}{|c|}{ Energy demand [kWh/a] } & Auxiliary electric energy [kWh/a] \\
\hline \multirow{5}{*}{ 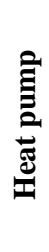 } & \multirow{4}{*}{ 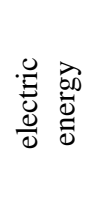 } & cooling & 48 & 244 \\
\hline & & hot water & 1157 & 382 \\
\hline & & $\begin{array}{l}\text { district heating } \\
\text { and ventilation }\end{array}$ & 4871 & 1093 \\
\hline & & sum & 6076 & 1729 \\
\hline & \multicolumn{2}{|c|}{ total sum } & \multicolumn{2}{|r|}{7795} \\
\hline \multirow{7}{*}{ 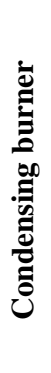 } & \multirow[t]{2}{*}{ gas } & $\begin{array}{l}\text { district heating } \\
\text { and ventilation }\end{array}$ & 15715 & \\
\hline & & hot water & 2662 & \\
\hline & \multirow{4}{*}{ 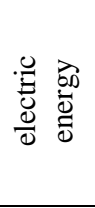 } & cooling & 48 & 244 \\
\hline & & hot water & & 382 \\
\hline & & $\begin{array}{l}\text { district heating } \\
\text { and ventilation }\end{array}$ & & 1092 \\
\hline & & sum & & 1871 \\
\hline & \multicolumn{2}{|c|}{ total sum } & \multicolumn{2}{|r|}{20248} \\
\hline
\end{tabular}

To calculate of annual cost operation the some assumption was made. In case of heat pump crucial thing was obtain individual cost of electric energy. It depends on electric developer and on energy consumption. For selected Polish developers costs of electric energy are presented in Table 3. That part of cost strongly depends on localization building on map of Poland.

Table 3. Tariffs of selected developer of electric and gas energy (cost netto, January 2011)

\begin{tabular}{|c|c|c|c|c|c|}
\hline $\begin{array}{c}\text { Electric energy } \\
\text { developer }\end{array}$ & Enea & $\begin{array}{c}\text { RWE } \\
\text { Stoen }\end{array}$ & $\begin{array}{c}\text { Energia } \\
\text { Operator }\end{array}$ & $\begin{array}{c}\text { Energia } \\
\text { Pro }\end{array}$ & Averange \\
\hline Constant cost $[\mathrm{z} / \mathrm{kWh}]^{*}$ & 0.5202 & 0.3777 & 0.4545 & 0.5996 & 0.4880 \\
\hline Variable cost $[\mathrm{z} / \mathrm{month}]$ & 5.07 & 6.07 & 4.22 & 2.59 & 4.49 \\
\hline $\begin{array}{c}\text { Gas energy } \\
\text { developer }\end{array}$ & Podkarpacka & $\begin{array}{c}\text { Dolnośląska } \\
\text { Gas Company } \\
\text { Company }\end{array}$ & $\begin{array}{c}\text { Mazowiecka } \\
\text { Gas } \\
\text { Company }\end{array}$ & $\begin{array}{c}\text { Wielkopolska } \\
\text { Gas } \\
\text { Company }\end{array}$ & Averange \\
\hline Constant cost $\left[\mathrm{zz} / \mathrm{m}^{3}\right]$ & 1.7491 & 1.4804 & 1.3419 & 1.3882 & 1.4899 \\
\hline Variable cost $\left[\mathrm{z} / \mathrm{month}^{3}\right]$ & 18.95 & 18.62 & 25.60 & 16.11 & 19.82 \\
\hline
\end{tabular}

* average day and night cost - two tariffs bill, based on [4]

If takes the gas energy under consideration, an annual volumetric demand has to be calculate. Assuming the average heat of combustion of natural gas as $H_{g}=26,23 \mathrm{MJ} / \mathrm{m}^{3}$ is possible to recalculate amount of gas consumption $m_{g}$ : 


$$
m_{g}=3,6 \cdot 10^{-3} \cdot Q_{g} \cdot H_{g}\left[\mathrm{~m}^{3} / \mathrm{a}\right]
$$

Presented data in Table 3 was taken for G-11 tariff for electricity and W-3 for gas as usually take place in detach houses in Poland. The annual cost of operation for presented above average costs of unit energy was obtain (Fig. 4).

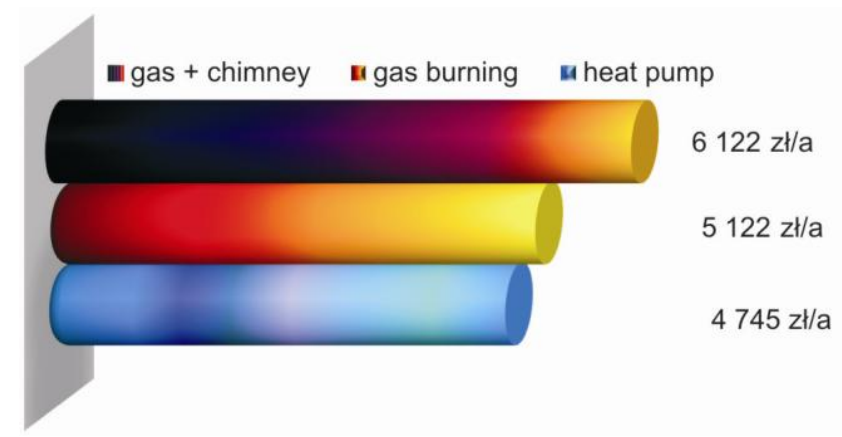

Fig. 4. Annual operation cost (plus VAT)

The difference between heat pump installation and gas combustion furnace is not significant but renewable energy source occurs a little bit better compare to common solution of building installation with gas condensation furnace. There is one aspect of this analysis not mentioned above. Installation with heat pump does not want the chimney as gas furnace. If one adds cost necessary to build a chimney than one finds out of advantage of heat pump installation. Approximately necessary costs to build chimney oscillate about 8000-12000 zł. Assuming life time period of installation operation for 10 years, the total cost connected to heat pump annual operation will be lower than system based on natural gas as a main source of heat energy production for building needing. The total annual payment for based installation is about $1000 \mathrm{zl}$. more expensive than previously. Heat pump installation has over $30 \%$ less operation cost than base variant with gas condensate furnace with chimney cost included.

Ratio of $\mathrm{CO}_{2}$ emission is obtained to necessary energy demand at developer. In case of electricity it is directly connected to GJ energy consumption by power station. Energy efficiency of carbon power station is average on $\eta_{e}=35 \%$ level, but nuclear power station is less - 30\% electric energy efficiency. In case of gas combustion the average energy efficiency is about $91 \%$. It means, power station must generate much more energy than is needed to support all building system to operate.

To obtain $a$ amount of annual energy consuming by analyzed building installation the energy efficiency must be considered according below equation. 


$$
Q_{a}=Q_{g} / \eta_{e}[\mathrm{GJ} / \mathrm{a}]
$$

The average $\mathrm{CO}_{2}$ gas emission for selected power station is taken from publication National System Administration of Emission Trade Permission and presented in Table 4 with annual energy demand in GJ/a.

Table 4. Tariffs of selected developer of electric and gas energy (cost netto, January 2011), based on [5]

\begin{tabular}{|c|c|c|c|c|}
\hline \multirow{3}{*}{$\begin{array}{l}\text { Energy production } \\
\text { fuel }\end{array}$} & $\mathrm{CO}_{2}$ emission & Energy & Unit $\mathrm{CO}_{2}$ emission & Energy \\
\hline & {$[\mathrm{kg} \mathrm{CO} / \mathrm{GJ}]$} & [GJJ/a] & {$[\mathrm{kg} \mathrm{CO} / \mathrm{GJ}]$} & [GJ/a] \\
\hline & \multicolumn{2}{|c|}{ heat pump variant } & \multicolumn{2}{|c|}{ condensation furnace variant (based one) } \\
\hline Local gas combustion & -1 & - & 55,8 & 73 \\
\hline $\begin{array}{l}\text { Power station for: } \\
\text { Black coal } \\
\text { Hard coal } \\
\text { Natural gas }\end{array}$ & $\begin{array}{c}94,8 \\
107,3 \\
55,8\end{array}$ & 80 & $\begin{array}{c}94,8 \\
107,3 \\
55,8\end{array}$ & 19 \\
\hline
\end{tabular}

If new energy demand necessary to produce by power station for analyzed building is known, there is an easy way to obtain emission of $\mathrm{CO}_{2}$ to atmosphere. The results of such analysis is presented in Fig. 5.

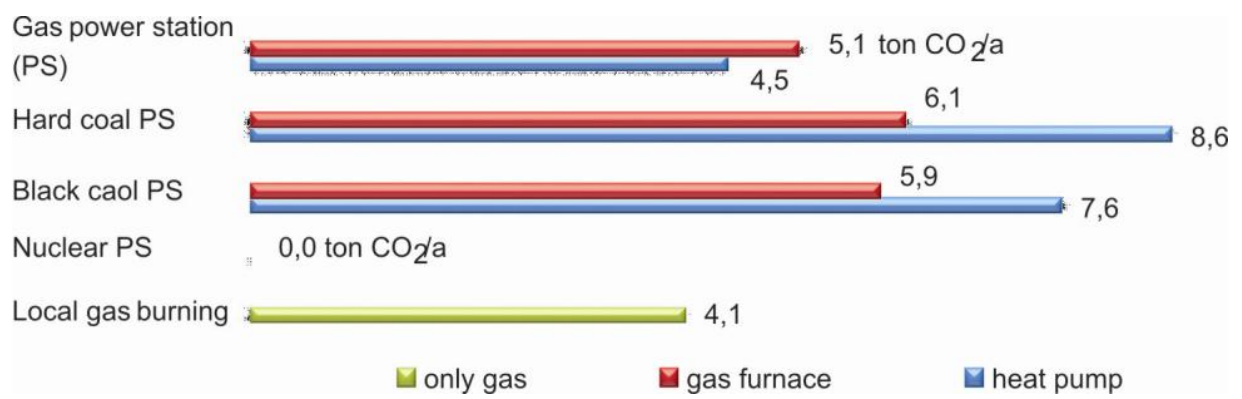

Fig. 5. Annual $\mathrm{CO}_{2}$ emission for two variants of installation

The most unfavorable situation occurs in case of electric energy in power station burning hard coal as a fuel. In base variant and variant with heat pump as well the largest $\mathrm{CO}_{2}$ emission has been reached -8.6 ton $\mathrm{CO}_{2}$ per year for heat pump and close to $29 \%$ for base variant. There is characteristic thing, larger greenhouse gases emission is for installation with heat pump feeding electric energy from coal power station - average of $25 \%$ more compare to gas combustion in condensation furnace in building. It is a unexpected conclusion, because 
of heat pump are considered as environmental friendly solution based on renewable energy source from ground. This is connected to low efficiency of electric energy production in coal power station. In case of electric energy production from power station with gas box the reverse phenomenon takes place. Emission of $\mathrm{CO}_{2}$ is over $14 \%$ lower for heat pump installation. The gas combustion itself locally, in servicing building cause the 4.1 ton of $\mathrm{CO}_{2} / \mathrm{a}$ emission what leads to $71 \%$ of overall greenhouse gases emission related to condensing gas furnace functionality.

The production of electricity from renewable energy sources as wind, water, solar radiation and electric energy from splitting of radioactive elements need to pay attention. Emission of $\mathrm{CO}_{2}$ from above energy sources in all cases is the same - ZERO.

In case of Heat pump installation the situation in more complicated. There is extra emission of greenhouse gases common known as freons or refrigerants. TEWI factor allows to recalculate refrigerant emission from heat pump installation itself for equivalent value of $\mathrm{CO}_{2}$. In Table 5 is presented emission related to selected refrigerants using in thermodynamic cycle of heat pump. This data was obtained for assumption of power of heat pump as $25 \mathrm{~kW}$. Analyzed installation works sequentially, 12 hours per day it is full of operational and the rest of day it is not working. During operational heat pump charging heat storage and supply heat energy for building. After the heat pump is off, all het for building come from heat storage during discharge cycle.

Table 5. TEWI for selected refrigerants applied in heat pump for 15 years lifetime period

\begin{tabular}{|c|c|c|c|c|c|c|c|c|}
\hline Refrigerant & R600a & R134a & R143a & R404A & R407C & R410A & R507A & R744 \\
\hline $\begin{array}{c}\text { TEWI } \\
\text { ton } \mathrm{CO}_{2} / \mathrm{a}\end{array}$ & 0.008 & 0.536 & 1.744 & 1.567 & 0.701 & 0.825 & 1.608 & 0.00067 \\
\hline
\end{tabular}

Refrigerants applied in heat pump leads to increasing of equivalent $\mathrm{CO}_{2}$ emission to atmosphere, average $11,2 \%$ per year.

\section{Conclusions}

Analyzed installation with heat pump allows to make some interesting conclusions. In spite of common conviction of environmentally friendly heat pump application there is not so obvious. The heat pump create more greenhouse gases than typical, traditional heating installation in detach houses and it strongly depends on type of power station which generate electricity to drive auxiliary equipment and motors in analyzed installation. The worst situation takes place in case of coal power station (Fig. 6). It is a little bit unexpected result, but rea- 
sonable. Power stations have still a very low electric efficiency, not more than $38-40 \%$ and this leads to large non renewable fuel consumption and large amount of $\mathrm{CO}_{2}$ emission. Unless the electricity is produce by coal and gas power station the $\mathrm{CO}_{2}$ emission will be large. Heat pump becomes environmental friendly installation only if the electric energy will develop a power station utilize the renewable energy as wind, water, sun radiation or other technology, for example radioactive elements.

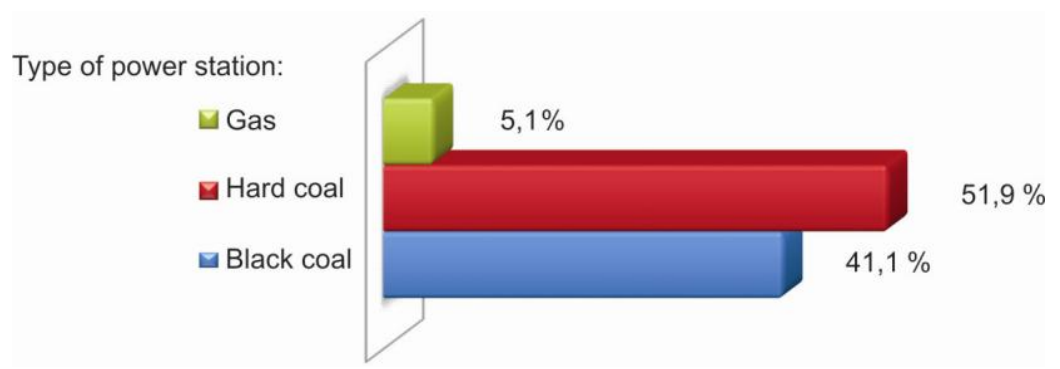

Fig. 6. Average percentage of greenhouse gases emission by heat pump installation (including TEWI effect) compared to gas condensing furnace

To illustrate how large effect of greenhouse emission is the simple example may explain all the problem. To connect the free $\mathrm{CO}_{2}$ from ambient air - generated only by one building installation with heat pump - necessary trees to assimilate this emission reach the value of 3.67 ar $\left(100 \mathrm{~m}^{2}\right.$ area) per year, if the 20 years old tree is taken under consideration with average absorption as $7.45 \mathrm{~kg}$ $\mathrm{CO}_{2} /$ a. It means, all lifetime of heat pump fully operational (15 years) needs 55 ar of 20 years old trees to assimilate $\mathrm{CO}_{2}$ from only one building. In case of base variant of installation the 42 ar is needed [6].

During installation a heat pump in building future users should be aware of consequences this decision for our environmental we share. The economical aspect is the most important, its obvious, but awareness of disadvantages of this behavior should take the significant place and well considered.

\section{Nomenclature}

$H_{g}$ - gas heat of combustion $\left[\mathrm{MJ} / \mathrm{m}^{3}\right]$

$m_{g}-$ annual mass of gases $\left[\mathrm{m}^{3} / \mathrm{a}\right]$

$Q_{a}$ - annual energy consumption by building [GJ/a]

$Q_{g}$ - building energy demand [kWh/a]

$\eta_{e}$ - efficiency of electric energy production [-] 


\section{References}

[1] Calm J.M., Hourhan C.G.: Refrigerant data summary, Engineered Systems, vol. 18(11), 2001, p. 74-88.

[2] Sand J.R., Fisher S.K, Baxter V.D.: Energy and global warming impacts of HFC refrigerants and emerging technologies, Oak Ridge National Laboratory, Tennessee 1997.

[3] Regulation of Infrastructure Ministry dated on November 62008 on methodology of energy characteristic of building calculation and habitable local or part of the building as technical integrity and model of energetic certificate and its energetic characteristic, Dz.U. Nr 201, poz. 1240 (Rozporządzenie Ministra Infrastruktury z dnia 6 listopada $2008 \mathrm{w}$ sprawie metodologii obliczania charakterystyki energetycznej budynku i lokalu mieszkalnego lub części budynku stanowiącej samodzielną całość techniczno-użytkową oraz sposobu sporządzania i wzorów świadectw ich charakterystyki energetycznej).

[4] www.instalreporter.pl

[5] Reporting at Union System of Emission Trade Permission for 2011 year. National System Administration of Emission Trade Permission, www.kashue.pl.

[6] $\mathrm{CO}_{2}$ Calculator. Methodology of $\mathrm{CO}_{2}$ accumulation by trees, Aeris Futuro Fundation, www.aeris.eko.org.pl.

\section{INSTALACJA Z POMPĄ CIEPLA A EFEKT CIEPLARNIANY}

Streszczenie

W pracy zaprezentowano instalację pompy ciepła dla budynków o małych kubaturach. Głównym celem pompy ciepła jest produkcja energii niezbędnej do systemów centralnego ogrzewania, wentylacji i przygotowania ciepłej wody. Dyskusji poddano wpływ pompy ciepła na emisję gazów cieplarnianych do atmosfery podczas prawidłowej pracy instalacji. Uzyskane wyniki emisji tych gazów zostały przeliczone na równoważną wartość emisji $\mathrm{CO}_{2}$ i porównane z instalacjami tego samego typu budynku, lecz bez instalacji pompy ciepła.

Słowa kluczowe: pompa ciepła, emisja $\mathrm{CO}_{2}$, globalne ocieplenie

DOI: $10.7862 / \mathrm{rb} .2012 .10$ 